\title{
CO-PRODUCTION, GOVERNANCE AND PRACTICE: THE DYNAMICS AND EFFECTS OF USER VOICE PRISON COUNCILS
}

Accepted Author Manuscript: Social Policy and Administration

Dr. Beth Weaver, School of Social Work and Social Policy, University of Strathclyde, Glasgow

beth.weaver@strath.ac.uk

ABSTRACT

Drawing on Bevir's (2013) decentered theory of governance, and Donati's (2016) theory of the relational subject, this article explores how User Voice Prison Councils in England have contributed to shifts in aspects of prison governance and practice. It discusses the cultural and policy context in which the Councils emerged and operate before exploring their perceived purposes, dynamics and effects. User Voice Prison Councils represent an important example of different actors co-producing alternative patterns of governance through innovations in democratic participation. Interviews with Prison Council participants, User Voice and Prison staff revealed that the development of such 'bottom up' participatory governance practices require and restore interpersonal trust, the mechanisms of which are interactions underpinned by a distinct manner of relating and the establishment of a network of relations oriented to the common good. The effects include enhanced institutional legitimacy; improvements in prison officer-prisoner relations; and greater quality of life for prisoners. Revealing the 'how' of coproduction, from the 'inside', the argument advanced here is that while the effects of coproduction may be more ameliorative than transformative, such collaborative and dialogic approaches can enable differently situated people to forge new norms of interactions and forms of democratic participation to achieve collective goals.

KEYWORDS: Coproduction, User Voice, Governance, Prison, Decentered Theory, Criminal Justice 


\section{INTRODUCTION}

European governments are encouraging greater citizen participation in, or coproduction of, the governance and delivery of public services (Pestoff, 2012). Coproduction, both as an ideology and practice, is, however, rarely associated with the management and operation of prisons (Weaver, 2011). User Voice Prison Councils are not only an exception but represent an important example of different actors co-producing alternative patterns of governance through innovations in democratic participation.

Coproduction is increasingly foregrounded in elite narratives, or formal discourses, of both policymaking and practice, which emphasize the role of service users, and communities, in contributing to the design, delivery and development of services (Weaver, 2011). Bevir's (2013) decentered theory of governance provides the theoretical framework for understanding how User Voice Prison Councils, in England, have contributed to shifts in aspects of prison governance and operational practice. Like wider accounts of governance, studies of co-production are often attached to reified concepts, utopian rationales or formal explanations and so elide 'the specific influence of time and place' (Bevir, 2013:4) and the associated individual and relational dynamics and, thus, the diversities and contingencies of governing practices and their effects. Rather than referring to abstract and decontextualized theories of governance, decentered theory enables an investigation into and explanation of 'the ways in which governance is created, sustained and modified by individuals acting on beliefs that ....arise from a process in which the individuals modify traditions in response to dilemmas' (ibid:50). This paper explores the interplay and overlap between those elite narratives informing the rise of coproduction and the local traditions and sites of resistance that interpret, operationalise or obstruct coproduction in practice, using empirical research examining the perceived purposes, dynamics and effects of User Voice Prison Councils. 
This paper commences by elaborating theories of coproduction and Bevir's (2013) decentered theory of governance, which, it is argued, might be enhanced by incorporating, alongside notions of situated agency, a theory of the relational subject (Donati, 2016). The following section discusses the cultural and policy context in which the User Voice Prison Councils emerged and operate. The penal landscape in England and Wales has undergone a substantial transformation in its organization and delivery, characterised by processes of devolution and deregulation and increased Governor autonomy, involving changes to the prison regime and staffing. The paper then discusses the evolution and operation of User Voice Prison Councils, which can be cast as a response to the dilemma posed by the democratic and legitimacy deficits emerging from traditional approaches to prison governance. Thereafter, it explores the perceived purposes, dynamics and effects of User Voice Councils. The paper concludes by suggesting that a decentered analysis can move narratives of coproduction beyond its current reliance on reified concepts and explanations of its transformative potentialities, towards a more nuanced, critical and complex view of such processes and their rather more contingent and ameliorative effects. It is suggested that the value of coproductive approaches resides more humbly in its capacity to enable differently situated but interdependent actors to forge new norms of interactions and forms of democratic participation and governance in order to achieve collective goals.

\section{COPRODUCTION AND DECENTERED THEORY: AN OVERVIEW}

The language of coproduction is increasingly dominant in 'elite narratives' (Bevir, 2013) or policy and practice discourses surrounding governance and service provision (e.g. Needham 2008), although the ideology of service-user empowerment and participation originated in the independent living and disability movements of the 1970s and 1980s (Harlock, 2009). The concept of coproduction is underpinned by diverse ideologies and their attendant narratives from notions of "public choice' characterised by an antipathy to 'big' government, and to its support of marketization and privatization (Bussu and Galanti, 2014)... to [notions of] citizen participation and development" 
(Durose and Richardson 2016:35). While New Public Governance is often cited as the contemporary framework to explore coproduction (e.g. Pestoff 2012), operationally, coproduction occurs in services more characteristically conceptualised in terms of New Public Management where service provision is dominated and shaped by a neo-liberal logic combined with doctrines of a managerial state, governed by market principles.

Co-production, as a form of governance manifesting (to different degrees) in democratic innovations is, essentially, a term for a particular type of relationship between services, service users and others from which an inherently different way of 'doing' services emerges. It denotes a range of collaborative practices, reflecting, in this context, the interdependent relationship between service providers and service users (Pestoff, 2012). Bovaird and Loeffler (2013:4) define coproduction as 'professionals and citizens making better use of each other's assets, resources and contributions to achieve better outcomes and/or improved efficiency'. User Voice Councils can be conceptualized as a collective form of coproduction in as much as it 'benefit[s] the whole community rather than just [individuals or] groups of users' (Needham, 2008:224). While the promise of coproduction tends towards the transformative (Filipe et al., 2017), in practice coproductive innovations are likely to build on, be shaped and constrained by existing frameworks and practices of governance, and thus more ameliorative in effect. How the 'distinctions and dilemmas of co-production play out' will vary between different types of public service, in different conditions and in different contexts (Needham and Carr, 2009:7). A decentered analysis can illuminate the dynamics of this 'undecided space' (Bevir, 2013:40) and the complexities and contingencies of coproduction in its situated context, which is a useful corrective to the decontextualized, normative and reified nature of the heuristics often produced in academia and policy.

Studies of governance are generally grouped into two principal theoretical traditions, Rational Choice and Sociological Institutionalism, which advance different assumptions about institutions, actors, and behaviors involved in policy-making and implementation. The neo-liberal account of 
governance has a synergistic relationship with rational choice theory. Both accounts, alongside public choice (e.g. Buchanan and Tullock 1962) and game theory (e.g. Osborne 2009) assume actions are a product of strategic, utility-maximizing individuals (e.g. Elser 1991), conceptualising actions as rational strategies for realising the preferences of actors and reducing motives to self-interest (Downs, 1957). However, even if an action engenders beneficial consequences for the actor, it does not necessarily follow that the actor acted intending to bring about those outcomes or, then, that it was motivated by self-interest (Bevir and Rhodes, 2001).

The most prominent alternative to neo-liberalism is accounts of governance that emphasize networks which evoke an institutionalist approach (e.g. Rhodes, 1997). March and Olsen (1984) define institutions in terms of operating procedures, understood as rules or norms, which explain the actions of individuals, treating actors in institutions as if bound to follow rules. Yet, not only can people choose to disobey a rule or understand and respond to rules in diverse ways but empirical investigations cannot interpret actors' beliefs, aspirations and motives from, for example, their role. Analyses of network governance similarly focus on their objective characteristics, treating networks as structures. This would erroneously imply that the dynamics of networks, the activities and practices of those comprising the network, and the aspirations, meanings and motives of the actors that shape them, can be analyzed from knowledge of their material dimensions, form and other characteristics.

Bevir's (2013) decentered theory of governance challenges these theories by using concepts of beliefs, traditions and dilemmas to explain people's constructions of what they are doing and their views on change. It enables an investigation into and explanation of 'the ways in which governance is created, sustained and modified by individuals acting on beliefs that are neither given by an objective self-interest nor by an institution, but rather arise from a process in which the individuals modify traditions in response to dilemmas' (2013:50). It involves exploring aspects of governance and explaining it by unpicking various 'traditions' (the set of inherited theories and associated 
practices shaping the way in which a person comes to hold beliefs and perform actions) and how actors within these traditions encounter and act to resolve 'dilemmas' (conditions of disquiet which arise whenever new circumstances generate a different belief that challenges their previously held beliefs).

Change occurs through actors encountering and responding to dilemmas posed to their inherited traditions; while individual responses to dilemmas are grounded in traditions, they respond to those dilemmas by replicating, modifying or developing them. Bevir emphasizes the role of 'situated agency' manifest in the diverse activity occurring in any given context, and which implies that any course of action is a contingent and reflexive individual choice, albeit situated in social contexts. Accordingly, 'no practice or institution can itself fix the ways in which its participants will act (hence their capacity for resistance), let alone the myriad ways in which they might innovate in response to novel circumstances so as to transform it' (Bevir 2013:26).

Decentered theory emphasizes the importance of historical explanations underpinning governance practices, which this paper attends to by discussing research into UK prison cultures, and the emergence of User Voice Prison Councils, below, and which informed the analysis. Governance comprises a set of diverse practices that people are constantly creating and recreating through their concrete or 'meaningful activity' (Bevir, 2013:25); it allows that 'people in the same situation could hold very different beliefs because their experience of that situation could be laden with very different prior theories' (ibid:25), which in turn, lead to 'dilemmas' they must work together to attempt to resolve.

The analysis of data revealed, however, a relational dimension to co-production which, alongside Bevir's emphasis on situated agency, requires a theory of the relational subject, suggesting scope for the future development of decentered theory. This paper proposes that there is an important analytic distinction to be made between reflecting on one's own beliefs, actions and performance and those of the collective. Acting in accord with one's own beliefs and standards, informed by 
traditions, is one thing. If I reflect on the collective's performance and on how this can be improved in the event that different actors relate to each other in a different way, I will seek to alter the performance of the collective as a whole and produce a different emergent effect (Donati, 2016). It is about not only evaluating, deliberating and acting in oneself, in the way that notions of situated agency imply, but in relation to each other as a collective and this is the difference between individual and relational or collective subjects. The relational/collective subject is constituted and shaped by internal relations between individuals that form part of it (i.e. a given User Voice Council) and by the external relations in which it is embedded (i.e. other prisoners, prison staff and so on).

\section{TRADITIONS: UK PRISON CULTURES IN CONTEXT}

While most prisons in the UK remain public organisations ${ }^{1}$, their functions, 'users' and the relatively closed nature of the organisation necessitate a mixed managerial approach which is not readily captured by any singular model of governance (Sangkhanate, 2012). Changes in prison administration since the late 1980s have increasingly manifested in privatization, deregulation and devolution, accelerating in recent years under the UK Coalition and Conservative governments (see e.g., MoJ, 2010; 2013a; 2016). However, at an operational level, prison activities in the UK tend to be conducted in a bureaucratic, hierarchical fashion (Sangkhanate, 2012), within a broader neopaternalistic approach (Crewe, 2009).

The impetus underpinning prison reforms is that devolution, deregulation and strategic management facilitate and incentivize change and induce innovation. However, if mutual trust underpins co-production (Bovaird, 2007), prison traditions pose distinct challenges (or dilemmas) to the implementation of co-productive and democratic innovations in prisons. Interpersonal trust is elusive in a prison context historically characterised by mutual distrust between prison officers and prisoners and between prisoners (Liebling et al 2011; Crewe 2011), with the prisoner community

\footnotetext{
${ }^{1}$ At the time of writing, out of 118 prisons in England and Wales there are a minority of 14 private prisons contractually managed by private companies such as Sodexo Justice Services, Serco and G4S Justice Services.
} 
typically (and increasingly) representing more of an individualistic than solidary culture (Crewe, 2009).

Early research into staff-prisoner relationships tended to polarize the two groups (i.e. Sykes 1958, Haney et al., 1973). Prison staff cultures are typically portrayed as hierarchical and authoritarian and staff-prisoner relations described in terms of 'a toxic hostility' (Sim, 2008:188), 'mutual contempt ...unprovoked aggression and antagonism' (Crewe, 2011:455) and suspicion and hyper-vigilance (Leibling, 2008). In reality, prison staff culture is as nuanced, variable and contingent as that of prisoners, with differences in the character of staff-prisoner relations evident both within (Sim, 2003 ) and between (McLean and Leibling, 2008) establishments. Crewe $(2009,2011)$ suggests that, in general, interpersonal barriers and enmities have diminished in UK prisons in recent decades, leading prisoners to describe staff as more approachable and less authoritarian. The evidence is, however, somewhat mixed; where Sim (2008:189) observes the devastating impacts and effects of officers' 'highly discretionary formal and informal power', Crewe identifies a diminution of their collective power and exercise of discretionary power, which he attributes to shifts in governance approaches as an outcome of neo-paternalism which comprises aspects of treatment and regulation that are accomplished through staff-prisoner interactions and indirectly through the policies that officers are required to implement. He observes that with an emphasis on self-regulation and responsibility, they are neo-liberal in character, but in the absence of compliance, prisons invoke authoritarian measures of control, sanctions and punishment. Drake (2008), on the other hand, suggests that in high security prisons, order is typically engineered through formal, procedural and situational mechanisms, rather than interpersonal negotiations and relations.

Crewe's (2011:457) argument is that 'the reduction of social distance between prisoners and uniformed staff has been achieved, to some degree, through mutual compulsion', rather than cooperation and collaboration, often underpinned on both sides by instrumental rationales (in the interests of security or personal progression). He suggests that 'officers are socialized to value the 
order and security dimensions of their work more than the rehabilitative parts' (ibid:463). While prison officers occupy different roles which include security, reform and rehabilitation, too often, those focused on reform and rehabilitation can be eclipsed by concerns with security in the wake of budget cuts, overcrowding and understaffing which can foster a sense of insecurity and can engender prisoner disquiet and resentment. This represents a concrete dilemma in which the role of enforcer of security becomes paramount. The dilemma arises perhaps in the dual role for prisons in both maintaining security and supporting rehabilitation (balancing custody and care) but neither can work without cooperation from prisoners.

\section{USER VOICE PRISON COUNCILS: EMERGENCE AND OPERATION}

There has been much emphasis on the need for public services to embrace innovation and to be informed by the needs and experiences of those affected. Threaded through this broader agenda, against which the emergence of User Voice Prison Councils can be situated, is a concern about the legitimacy and accountability of state institutions and partners. It is widely accepted that services that engage with users are more efficient and effective. It is in the context of democratic and legitimacy deficits in prisons in the UK (Liebling et al., 2011), juxtaposed with wider shifts in public policy (emphasising participation) and the governance of prison services (emphasizing selfregulation) that the User Voice model of Prison Councils emerged.

Since the Strangeways Prison riots and the Woolf Report (1991), local prison managers have recognised the need to establish legitimacy and encourage cooperation amongst prisoners (Solomon and Edgar, 2004). The rationale for this, however, is far more ameliorative, if not instrumental, in aspiration than democratic in orientation, transformative in effect and normative in intent. This might, in part, explain why the U.K. Prison Service has resisted a national policy on this form of engagement despite the fact that European Prison Rules (Council of Europe, 2006, Rule 50) specifically recommend that prisoners are enabled to discuss prison conditions and processes with prison management and explicitly encourage the establishment of prison councils and related 
structures (Bishop, 2006). Internationally, a number of countries have, to different degrees and with different effects, made legislative provision for prisoner participation (Bishop, 2006; Solomon and Edgar, 2004).

Aware of these deficits within the Prison Service and informed by their own experience of the criminal justice system, User Voice was established in 2009 as a user-led charitable organisation whose aim is to 'foster dialogue between service providers and users that is mutually beneficial and results in better and more cost-effective services' (User Voice, 2012). The origins of their Council model thus lay in this awareness of shortcomings in a system designed primarily to work 'on' rather than 'with' prisoners, and Councils were proposed by User Voice as a means of changing this dynamic.

Little empirical research has been conducted on their value to prisoners, institutional dynamics, or overall environment. Solomon and Edgar's (2004) study was an exception, suggesting that traditional $^{2}$ councils can give prisoners a crucial voice; provide feedback on policy changes; engender a greater sense of responsibility amongst prisoners; and promote active citizenship and successful rehabilitation. By utilizing prisoners' perspectives, in principle, prisons can reorganize their service and regime procedures, which could result in cost-saving measures, the elimination of redundant services, all while increasing user and staff satisfaction. In practice, however, they found that traditional councils were used to air personal complaints and pursue individual agendas, engendering resentment among staff. Distinctively, User Voice Councils are oriented towards matters of collective concern, proposing solutions, rather than airing individual complaints; they are designed to work with rather than against prison regulatory frameworks; and aim to be representative rather than elite, operating on mechanisms of representative democracy (User Voice, 2010). In practice, Council Members, across this sample, were predominantly older, serving long(er) sentences, were engaged in related initiatives (as Listeners, wing representatives, or mentors), and

\footnotetext{
2 'Traditional councils' refers to those council structures that pre-dated the introduction of User Voice Councils.
} 
nearly all were 'enhanced' prisoners, as per the Earned Incentives and Privileges (IEP) policy ${ }^{3}$. While Councils Members are elected by their peers, IEP was generally used as a guide to vet potential Council Members, (typically determined by the prisoner's 'security risk'), at the discretion of prison management rather than User Voice staff. While issues of representativeness have been an enduring debate in, and critique of, user involvement initiatives (e.g. Croft and Beresford 1990), nearly all participants believed that vetting was an appropriate and useful method to ensure the Council recruited 'committed' and 'trustworthy' members, while ensuring diversity.

Consultation between elected Council Members and other prisoners inform the development of proposals for change that are the subject of Council meetings (discussed below). User Voice employees attend regular meetings with Council Members. Monthly meetings with the Governor involve a discussion in which the proposals are negotiated and agreed. Agreed proposals are thereafter discussed at monthly Council meetings, chaired by the Governor and can include a diverse range of affected and interested parties.

User Voice Prison Councils can be described as 'participatory and dialogic' (Bevir, 2013: 205), oriented to promoting 'democratic values...involv[ing] consultation [and] decision-making' (ibid). User Voice, as an independent organisation, operates as a mediating agency in a coproductive partnership with prisoners and prison staff but the inclusion of prisoners confers greater legitimacy and generates an enhanced level of trust from the prisoner community than has historically been the case. While prisons often had pre-existing alternative structures for user participation, variously referred to as Prisoner Information Desks (PIDS), Prisoner Consultative Committees (PCCs) or Prisoner Consultative Groups (PCGs), they have not historically benefited from senior management 'buy-in'. Despite the support of senior management, however, the early User Voice pilots (User Voice, 2010) suggest considerable scepticism among prison officers. This relates to issues of power,

\footnotetext{
${ }^{3}$ The IEP policy was introduced in 1995. The rationale was that privileges should be earned by prisoners through good behaviour and performance and can be removed where expected standards are not met.
} 
for example, that Councils might mean that staff are being 'managed' by prisoners or that prisoners would have more access to senior staff than prison officers.

User Voice thus redesigned traditional prison councils around principles and methods used in other democratic fora in response to what they and others identified as democratic and legitimacy deficits in the original approach, and which represented 'a dilemma'. Against traditions of power, security, authority and control, User Voice (2010) identified that the purposes of prison were unlikely to be realized in existing governance arrangements where things are done to people, breeding a 'them and us' mentality. Reform depends, User Voice (2010) argue, on the assumption of responsibilities and rights and indeed the efficacy of services and the realisation of both objectives of security and rehabilitation depends on prisoner cooperation and engagement.

\section{METHODS}

The paper draws on a wider mixed method study, commissioned by User Voice, whose overarching aim was to determine the impact of User Voice Prison and Community Councils on individual participants and services as well as the wider social environment (see Barry et al., 2016). The research took place in three areas (A, B and C), including six prisons, between May 2014 and March 2016. Ethical approval was granted by the University's Ethics Committee and the National Offender Management Service. This paper draws on interviews with five key project implementers and advisors, 21 Prison Council participants and three Prison Council non-participants ${ }^{4}$ : two in Area A and one in Area B. Prison Council interviewees ranged in age from 28-56 years old. Two were on remand, one was convicted and awaiting sentencing, and one was serving a life sentence. The remaining 17 were serving sentences that ranged from 3-27 years. Active involvement in the Council ranged from six weeks to more than two years. The analysis further draws on interviews with 11 User Voice staff, volunteers and mentors, eight prison officers, six Prison Governors and two Senior

\footnotetext{
4 'Non-participants' were defined as those who had previously been involved in the prison council, but had since ceased participation due to their choosing or had been involved in the council limitedly and/or for a short period of time (less than two to three months) before deciding to withdraw.
} 
Managerial staff in User Voice. Interviews were recorded and transcribed verbatim. An inductive, thematic approach to analysis was undertaken (Braun and Clarke 2006), identifying key themes through a process of repeated reading of the data and the manual generation of initial codes according to thematic areas of inquiry broadly outlined in our interview schedule, which were common to the majority of respondents but also identifying outliers and differences between the case study areas. Thereafter, like categories of data were collated in a master list of major codes, further sorting the codes into themes and sub-themes, and assembling relevant coded data-extracts into the identified themes. The centrality of social relations to the purposes, dynamics and effects of User Voice Prison Councils emerged during the 'first order' analysis of the data; the conceptual framework outlined above was used as the theoretical lens informing the 'second order analysis'. The themes discussed below are broadly characterised in terms of purposes, dynamics and effects.

\section{FINDINGS}

\section{Perceived Purposes and Rationales}

Perceptions of the purposes of User Voice Councils by senior prison management and prison officers were to provide a formalized structure to facilitate a two-way consultative process, primarily between prisoners and senior management. The overarching objective of this dialogic process is to work collaboratively, as a collective, to improve how prisons operate, informed by an understanding of how they are experienced, to generate mutually beneficial outcomes for prisons, their staff and prisoners thus oriented to the common good.

To make changes and to improve the lives of everybody in this community, staff and prisoners. It's not just for the benefit of prisoners. I think if we can do something that does enhance and benefit prisoners' lives, then that helps us... as well (Prison Officer, Area C). 
Some Governors also described the purpose of the Prison Councils in reducing prisoner disquiet and disaffection, in creating a legitimate channel (perhaps ironically) for the Governor's voice to be heard, and in changing prison culture to one of mutual respect and encouraging self-regulation.

The issue about less staff around means that you need [prisoners] to be able to solve issues for themselves ... there's a lot of people ... getting prisoners involved in running prisons now because they've been forced to because they haven't got the staff, and benchmarking takes a lot of money off people (Governor, Area C).

This emphasis on consultation is, then, a partial response to dilemmas posed by the Transforming Rehabilitation agenda but one that risks the Councils acting as a sounding board or even, as one participant suggested, a means of 'road testing' new policies. This interpretation echoes Needham and Carr's (2009) concept of 'intermediate' (rather than transformative ${ }^{5}$ ) levels of coproduction, which denotes a greater level of communication with and involvement from, in this case, prisoners. While this can enhance mutual recognition and understanding, it can also legitimize existing approaches and help service users appreciate the constraints on service provision.

Consultations between Council Members and prisoners inform the development of proposals, which tend to focus on aspects of service delivery and prison conditions (e.g. allocation of clothing; improvements to visits areas; and the provision of in-cell phones). 'Like any democratic process' (Prison Officer, Area C), the manner in which these proposals are selected is achieved through a process of discussion and negotiation and 'because it's a democratic society, the majority, we go with it' (ibid). Both User Voice employees and participating prison staff therefore influence the proposals advanced by Council members, on behalf of prisoners, to ensure they are 'realistic' and do not conflict with institutional or wider penal policy - or inflame public sensibilities.

\footnotetext{
${ }^{5}$ Transformative levels of coproduction require a shift in power and control through the development of new user-led mechanisms of planning and delivery, management and governance, such that co-production is embedded in organisational governance as opposed to discrete opportunities for collaboration.
} 
We have to make sure the proposals are in line with prison service orders or ... instructions and with that would come the Grayling ${ }^{6}$ agenda....because otherwise you're setting the Council with a real sense of unrealistic expectations (Prison Officer, Area A).

I think we go by the rule of ...is there any written policy that will affect this proposal? Will it pass the Daily Mail test? So will the general public object to what we're looking to propose?...Public opinion does affect policy whether we like it or not and that can be to the detriment of the lives of serving offenders (User Voice Staff, Area A).

Some Governors, while recognising the enhanced legitimacy that User Voice, as an independent agency led by people with lived experience, brought to prison councils, suggested that the model should occupy a more strategic and 'diagnostic' role in prisons. These extracts highlight different perceptions of the utility or purposes of Councils, and some of the dilemmas that different actors encounter in the light of their inherited traditions and situations. It also illustrates the processes through which practices of governance are created and recreated. As a response to democratic and legitimacy deficits in prison governance, User Voice are forging their own governance practices by resisting elite, consumerist or neo-liberal narratives of coproduction, for example, by focusing on democratic innovations more broadly. Their utility from a managerial perspective, however, further resides in ameliorating the dilemmas posed by policy directives that can undermine prison stability and/or security in accordance with policy priorities and public sensitivities. In turn, the seemingly convergent yet disparate discourses - of customer orientation, governor empowerment, prison performance versus inclusion, democracy and voice - give rise to new dilemmas where they are differently interpreted and encountered by different actors for different ends.

One of the distinctive features of User Voice Prison Councils are that they are intended for 'everybody'; the extent to which this purpose is realised in practice is constrained, in certain

\footnotetext{
${ }^{6}$ The Secretary of State for Justice in the UK between 2012-2015
} 
contexts, by the absence of 'buy-in' from, and the limited participation of, operational staff in Council meetings (discussed further below).

The User Voice model...is not a prisoner Council but a prison Council with the distinction being it belongs to everybody who works and lives in the prison, and that changes the whole... sense of ownership (Scoping interview 3).

Council Members' rationales for participation, and thus, perceptions of purposes were oriented to improving conditions for those living and working within the prison, with a few emphasising a desire to better the environment for future prisoners (i.e., leaving a 'legacy'). Many saw Council participation as a form of 'giving back' to the prison community. All interviewees felt that 'having our voice heard' was invaluable, not only for identifying problem areas (and solutions), but also because most felt their voices were usually silenced within the prison setting. Council Members typically expressed their motivations and Council intentions towards the common good of the collective (their 'prison community'), to improving systems and relationships, rather than simply personal progression or self-interest.

'Basically ... to make [the prison] a better place... So it's not just about prisoners, it's about how we lend a voice to staff and to visitors...I think the Council is toward benefiting a prison population but enhancing the skills and giving people the opportunity to prove themselves' (Council Member, Area A)

User empowerment and democratic engagement to coproduce solutions to collective concerns, and thus the development of a collaborative approach to aspects of prison governance, are the principal objectives underpinning User Voice Prison Councils. They are also apprehended by some prison Governors as a means to improve the perceived performance and legitimacy of their prisons. This reveals some divergences, though not necessarily incompatible differences, between different 
participants. However, Prison Councils also met some resistance from other prison staff and prisoners alike.

\section{The Dynamics of User Voice Councils in a Prison Context}

User Voice Prison Councils are unique, partly because their staff are 'ex-offenders' who work coproductively with both prisoners and staff. Being managed and run by a user-led organisation offers credibility, accountability and legitimacy, not only amongst the commissioners of the Councils but also prisoners.

I engaged because [User Voice staff member] knows what this is about. He's done time and knows how prisons work ... It wouldn't be the same if someone else came in and tried to tell us about change or prison life ... He knows our frustrations - he's been there and has felt it himself ... I don't think I would have been interested if he wasn't a con (Council Member, Area B).

The user-led aspect of User Voice encourages identification-based trust, defined by Fledderus et al., (2013) as an emotional or affective process enabled by mutual recognition and understanding of each party's objectives, goals and values. Their legitimacy is further underpinned by prisoners' perceptions of a reduced social distance compared to that existing between themselves and prison officers, based on shared experience. User Voice, as an intermediary between differently situated actors, are also considered adept at working collaboratively with 'function heads' in prisons and, as an independent external agency, can hold staff to account to ensure that proposals are implemented as planned. One Governor said that User Voice staff had a 'unique dynamic', or manner of relating, in terms of effectively engaging both staff and prisoners and holding both to account.

I just liked the concept and the idea of User Voice because it leads to accountability (Council Member, Area A). 
Things are being achieved. The managers ...now have to take a vested interest in what's happening...they are answering questions now... [Prisoners] are not always gonna get what they want but they know things will be listened to and a decision will be made (Prison Officer, Area C).

Council meetings are generally well attended by Council Members and senior prison management and, indeed, a commitment from the highest echelons of senior management to the Councils was common to all three areas. This leadership is central to the effective implementation, operation and outcomes of the User Voice Council model. Despite the unanimous support from those directly participating in the Councils 'every state department contains departmental traditions, often embodied in rituals and routines' (Bevir, 2013: 68). It includes processes of socialisation into 'the idea of a profession' through which they 'learn the framework of the acceptable' (ibid). In prison, both the presence of User Voice and the introduction of their Council represent shifts in processes and practices of governance that pose specific dilemmas to the traditions of prisoners and staff. The dilemma arises for prisoner officers where a focus on empowerment, voice and choice is perceived to undermine their traditional roles of maintaining order, discipline and control.

While the Councils emphasise self-regulation and responsibility in a democratic sense, this is at odds with the emphasis on self-regulation and responsibility emerging from neo-paternalistic approaches to regulation, which emphasise compliance with the system rather than challenges to it. Given the buy-in from Senior Management and the expectations, if not requirements, on prison officers to cooperate, these seemingly contradictory demands manifested in disparate views towards the Council and perceptions of what it implies. This engendered staff resistance to, or obstruction of, the Council's operations across all three areas, attributed, in part, to an implied fear of undermining professionalism, where the Council represented a blurring of professional boundaries and a shift away from traditional hierarchical power relations towards a more cooperative relationship between staff and prisoners. 
Some [staff] embrace it but then...some people... [have been] involved in the system for so long where they've been involved through many years of change ...one minute they're law enforcers, one minute they would be helping people...and so I feel that it is overwhelming for them (User Voice Staff, Area B).

For example, User Voice employees are permitted to carry keys in some prisons. However, the position of key carrier signalled a shift in the perceived difference and boundaries between prison officers and User Voice staff and between prison officers and prisoners - not least because some User Voice employees were formerly incarcerated in the same institutions. While conveying trust from senior management in prison, in a culture historically characterised by distrust, this symbol of institutional trust equally detracted - initially at least - from User Voice's perceived trustworthiness, amongst some operational staff and prisoners.

One of the big things we initially had to deal with was...the User Voice representative, who is an ex-offender...walking round with keys and a lot of staff in the early stages... didn't agree with it. Some of the prisoners also resented [name] cos they used to think cos he's an exoffender but now he's got keys he's on the staff side, he wants to represent them (Prison Officer, Area C).

Explanations for this distrust and resistance included being 'sceptical of...empowerment for prisoners' (Prison Officer, Area C) and hostilities generated by a 'them and us' mentality (Volunteer, Area B). Although the vast majority of interviewees were optimistic about the success and progress of their Councils, there was consensus that the attitudes of staff, alongside the exigencies of the regime, can 'make or break Council efforts'. Many prisoners recounted examples of resistance to, or obstruction of, the Council's operations: officers not unlocking Council members or unlocking them late for meetings; resisting Council initiatives ('this is my wing and I'll run it how I see fit'); and meetings having to be cancelled or postponed due to lockdowns or 'staff shortages'. Some described how officers would comment on their relationship with the Governor ('you see him more than I do'; 
'you've got the ear of the Gov' - he's never even spoken to me'). Prison officers who perceived the User Voice Council as a Prisoner rather than Prison Council struggled to relate to, support or even identify a benefit of the Council model. While one prison officer (Area C) suggested that 'staff have a voice' (for example through the Prison Officers Association), many felt their voices went unheard. There was resentment by some prison staff that prisoners were getting prime time with the Governor when they did not.

It's a Prisoner Council as far as I'm concerned, made up of prisoners. There doesn't seem to be any other voices heard (Prison Officer, Area C).

You've got a lot saying, well why are they getting listened to when nobody bothers listening to us? (Prison Officer, Area B).

The prison estate was trading on goodwill and it was running out fast. When they saw that we were getting an audience with the prison governor, the comments they were making was - well, they're not listening to us...there's value in just listening to people and nobody feels heard these days (Volunteer, Area B).

These findings indicate a relationship between staff empowerment and how they view prisoner engagement and their role in governance. One prison officer suggested that staff buy-in would be encouraged if it also addressed 'things that might be beneficial to the staff as well, so it's not all just about prisoners, it's not all prisoner-led because staff do feel very undervalued at the moment, very demotivated' (Prison Officer, Area B). Such feelings can, at least in part, be attributed to wider cultural, organizational and operational changes, partly required by the Transforming Rehabilitation agenda (MoJ, 2013b), which have affected resistance to the introduction of the Council model and to participation in it: 
It was difficult in [Area C] in the beginning because we went to [Area C] just after they'd been privatised, so you can imagine how the staff looked at us, coming in, they'd lost 200 and odd staff and they bring ex-cons in here (User Voice Staff, Area C).

The prison was at the point ...[of] changing from HMP to [private firm], so that had a huge impact on how the staff were feeling...it was just too much too soon for the staff (User Voice Staff, Area A).

Limited participation by operational staff in Council meetings was generally attributed to reduced staffing levels and increased workloads. In this context, it was suggested that the prison officers that did attend were instructed to by the Governor for specific reasons. In Area B, prison officers were said to be 'dragged along...to answer why they haven't done things or to be told to do things' (Prison Officer, Area B).

Some prisoners were also sceptical: Council members were construed by some prisoners as 'screw boys, officers with no keys' (Prison Officer, Area C). Such resistance can be understood as a dilemma posed to prisoner traditions by a new way of working - with the system rather than against it.

The older generation...they may have done lots of previous time in custody and ...they're not comfortable with the whole process (Prison Officer, Area A).

The culture of prisons, prison staff and managers and prisoners themselves, is such that it is very, very difficult for them to take on board those issues in a different way. People are very culturally programmed to operate in a certain way (Governor, Area B).

Overall, however, the model was seen as effective in empowering prisoners and offering solutions to shared problems.

\section{The Impacts and Effects of Prison Councils}


A range of effects and outcomes for individuals were identified as a consequence of participation in the Council. Communication skills, confidence, increased self-efficacy, self-worth, and finding purpose and meaning in their lives through helping others were the most common benefits. All interviewees felt that having their voice heard was invaluable, and at the heart of Council participation and effecting change. The operational outcomes engendered by the Councils included the provision of in-cell phones and the provision and distribution of clothing, a telephone monitoring and maintenance system, a calmer environment, and improvements to visit areas. These outcomes are oriented to an improved quality of life thereby contributing to improved service delivery.

Notwithstanding the resistance of some prison staff, the relational outcomes reported by many participants suggested that the Councils had contributed to the reduction of some of the historical 'barriers' that existed between staff and prisoners and to improved relationships, particularly between those active in the Council, and reinforced the need for a more participatory, collaborative and coproductive approach. Some User Voice staff identified a shift in interpersonal dynamics and the development of mutually respectful relationships, which was enabled by regular face-to-face interactions, their interdependence and interactions, which is generally cooperative and solidary in nature. While this was necessary to producing outcomes, it engendered personal outcomes for participants that were symbolic in effect. As noted, participants reported an enhanced sense of selfefficacy, reinforced by the tangible operational outcomes they co-produced, which signified Council Members, in their own eyes and the eyes of others, as influential. Moving away from negative labels (like 'con' or 'offender') toward 'a person of value' was critical to reshaping one's identity. Being viewed or treated 'as an individual and not just a number' enabled many to see their own capacity and worth, and enhanced perceptions of self-efficacy. Council participants felt 'valued', 'recognized', and 'listened to' as an outcome of Council participation. 
Prison staff talk to me more like. .. a person, not just an inmate ... We have conversations, and just banter. It's normal - about as normal as it could ever be, but it's just like we're two guys on the street ... [That officer] was the one who suggested the Council to me. He had seen something in me ... thought l'd be good at it ... It makes you feel good to have someone point out your strengths, because you can't always see them yourself, especially in a place like this (Council Member, Area A).

Participants also found satisfaction in helping others 'negotiate the system', 'lending an ear', or feeling as though they were accomplishing something constructive for future prisoners. Council participation fostered a sense of connectedness and inclusivity enabling members to feel like productive citizens within the prison community.

With the Council, right, we come together. We're made to feel like someone's listening and that we can be part of it; part of making it a better place (Council Member, Area A).

Helping others was also linked to stability, civility, and assisting others in finding constructive outlets for their frustrations, and in this sense, contributed to changes in interpersonal relationships and how the prison environment is experienced. For example, it was generally considered that the implementation of positive changes improved quality of life and relationships, enhanced cooperation and reduced conflict. This enabled prison officers to engage in proactive practice rather than reacting to issues arising from discontent and unrest.

There was a lot of problems and people were always moaning and trying to kick off on the wings. You're always gonna get teething problems, so obviously we thought, this Prison Council ... you sit before the Governor and he will listen to you and he will want to make a change. So I thought, yeah, I would like to help other prisoners, so this is why I engage 
because... I think about ... what other people could benefit from. It's like a legacy you leave behind for other people (Prison Council Member, Area A).

In sum, User Voice Council impacts are generated in a dynamic manner involving mutual interaction between different individuals and groups, and the participating prisons. Changes in the way in which staff and prisoners engage with each other underpin shifts in prisoners' perceptions about the legitimacy and responsiveness of services, and, in turn, enable a more participatory and democratic approach to prison governance, oriented to improving services and resolving disputes between differently-positioned but nonetheless interdependent actors.

\section{CONCLUDING DISCUSSION}

Moving beyond idealistic or utopian accounts of coproduction that limit our capacity to understand how coproductive innovations are experienced and responded to in a real world context, this article advances a decentered analysis to explore the interplay between elite narratives and how coproduction is operationalized and resisted on 'the ground' using empirical research into the purposes, dynamics and effects of User Voice Prison Councils in the UK.

To reveal the 'how' of coproduction, from the 'inside', and, as part of that, to properly analyze the dynamics, processes and outcomes of participatory, democratic and dialogic approaches to governance, within which coproductive innovations can be situated, the analysis advanced here suggests that the inclusion of a concept of the relational subject to a decentered analysis can illuminate the dynamics and contributions of collective actors and thus an analysis of the relational dimensions of coproduction in situ. The relational subject is not only one who acts reflexively taking into account their relations with significant others, but who operates with and through social relations (Donati, 2016). It is, then, imperative to understand how such operations happen and are configured, which is enabled by a decentered analysis. It is suggested that actors not only evaluate, deliberate and act in the way that notions of situated agency imply, but in relation to each other as a 
collective, while avoiding the reification of such collectivities as structures. Social relations are not structures that impinge on individuals or make them act in certain ways, but emergent effects of interactions. While further research into the relational dynamics and dimensions of coproduction in different contexts is required, such a framework could inform future academic analyses of patterns and practices of governance.

Based on the foregoing analysis, User Voice Councils can be conceptualised as a dialogic and participatory collective oriented to the common good. Generating the common good presupposes the relational participation of those involved and affected; coproduction as a theory and a practice is, then, a generative process for pursuing, if not realising, the common good, for those within and outwith the collective.

'What characterizes the common good is the fact that the advantage each person derives from belonging to a certain association or community cannot be severed from the advantage that others also derive from it. This means that each person's interest is realized together with that of others, not in opposition to it' (Donati, 2014:32).

Coproduction can thus be understood as a generative, rather than transformative, process that creates the space for new forms of relating, for differently situated people to produce new norms of interactions and forms of democratic innovations, incrementally reducing social distance and ameliorating pre-existing power imbalances, at least amongst those active in the Council, to achieve collective goals. Such effects are, however, dependent on the nature of the relations that characterize the collective endeavour, which require reflexivity, reciprocity and interpersonal trust. As Bovaird (2007:856) observes:

'Coproduction means that service users and professionals must develop mutual relationships in which both parties take risks - the service user has to trust professional advice and 
support, but the professional has to be prepared to trust the decisions and behaviours of service users...rather than dictate them' .

Nonetheless, sites of active resistance to and obstruction of Council activities occurred among some prisoners and prison staff not directly involved in the Councils, fuelled by distrust, and influenced by a perceived blurring of traditional role-relations and threats to their 'traditions' in moving traditional hierarchical power relations towards a more cooperative relationship between staff and prisoners. Changes to working conditions and perceptions of the erosion of their authority coupled with a lack of voice, contributed to the resentment of prison staff whose lack of involvement hindered 'buy-in' and understanding of the role of Councils to their work, its purposes and potential outcomes. Given the apparent relationship between staff empowerment and their attitudes towards prisoner engagement in governance practices, greater engagement with, and involvement of, operational staff in the activities of the Councils might increase their buy-in to the process and outcomes, which might also enhance its credibility and sustainability within such traditionally hierarchical environments.

Decentered theory, unlike other theories of governance, opens up the concept of the institution to incorporate meanings, as a product of actions informed by the varied and contingent beliefs and desires of relevant actors. This article thus reconfigures scholarly interpretations of coproduction by looking behind the reified concepts, formal explanations and normative implications that dominate academic and policy narratives of its transformative potentialities, advancing a more nuanced, critical and complex view of its process and its rather more contingent and ameliorative effects, thus grounding its value in its capacity to enable differently situated but interdependent actors to forge new norms of interactions and forms of democratic participation to achieve collective goals oriented to the common good.

\section{REFERENCES}


Barry, M., Weaver B., Schmidt., B and Liddle M., with Maruna., S (2016) Evaluation of the User Voice Prison and Community Councils, Nesta http://www.nesta.org.uk/user-voice

Bevir, M., (2013) A Theory of Governance, available online at: http://escholarship.org/uc/item/2qs2w3rb

Bevir., M., and Rhodes, R. A. W., (2001) A Decentered Theory of Governance: Rational Choice, Institutionalism and Interpretation. Institute of Governmental Studies, University of California, Berkeley, Working Paper 2001-10

Bishop, N., (2006) Prisoner Participation in Prison Management. Prison Field, Vol 3.

Bovaird, T.., (2007) Beyond engagement and Participation: User and Community Coproduction of Public Services. Public Administration Review 67: 846-860

Bovaird, T and Loeffler, E (2013) The Role of Co-production for Better Health and Wellbeing in Loeffler, E., Power, G., Bovaird, T and Hine-Hughes, F., (2013) Co-production of Health and Wellbeing in Scotland. Governance International.

Braun, V. and Clarke, V. (2006) Using Thematic Analysis in Psychology Qualitative Research in Psychology, 3 (2): 77-101

Bryans, C.S., (2005) Prison Governance: An Exploration of the Changing Role and Duties of the Prison Governor in HM Prison Service http://etheses.Ise.ac.uk/id/eprint/2418

Buchanan, J.M., and Tullock, G., (1962) The Calculus of Consent: Logical Foundations of Constiutional Democracy. Ann Arber: University of Michigan Press.

Crewe, B., (2009) The Prisoner Society: Power, Adaptation and Social Life in an English Prison. Oxford: Oxford University Press, Clarendon Studies in Criminology.

Crewe, B (2011) Soft Power in Prison: Implications for Staff-Prisoner Relationships, Liberty and Legitimacy European Journal of Criminology 8(6): 455-468 
Croft, S., and Beresford, P., (1990) From Paternalism to Participation: Involving People in Social Services. Open Services Project/Joseph Rowntree Foundation, London.

Donati, P., (2014) Relational Goods and Their Subjects: The Ferment of a New Civil Society and Civil Democracy, Reberca, Revista de Pnament I Analisi 14: 19-46

Donati, P., (2016) The 'Relational Subject' According to a Critical Realist Relational Sociology. Journal of Critical Realism 15(4): 352-375.

Downs, A., (1957) An Economic Theory of Democracy. New York, Harper and Row.

Drake, D., (2008) Staff and Order in Prisons in Bennet, J., Crewe., B and Wahidin A., (eds) Understanding Prison Staff, Cullompton, Devon pp157-167

Durose, C and Richardson, L., (2016) Designing Public Policy for Coproduction: Theory, Praqctice and Change. Policy Press.

Elser, J., (ed) (1991) The Economic Approach to Politics. New York, Harper Collins.

Filipe A, Renedo A, Marston C (2017) The co-production of what? Knowledge, values, and social relations in health care. PLoS Biol 15(5): e2001403. https://doi.org/10.1371/journal.pbio.2001403

Fledderus, J., Bransden, T., and Honingh, M., (2013) Restoring Trust Through the Coproduction of Public Services: A Theoretical Elaboration, Public Management Review 16(3): 424-443

Haney, C., Banks, C., and Zimbardo, P., (1973) Interpersonal Dynamics in a Simulated Prison. International Journal of Criminology and Penology 1: 69-97

Harlock, J., (2009) Personalisation: Rhetoric to Reality: London, National Council for Volunttary Organisations.

Liebling, A., Helen, A., and Straub C., (2011) An Exploration of Staff Prisoner Relationships at HMP Whitemoor: 12 Years On. Ministry of Justice. 
McLean, C., and Liebling, A., (2008) Prison staff in the Public and Private Sector in Bennet, J., Crewe., B and Wahidin A., (eds) Understanding Prison Staff, Cullompton, Devon pp92-113

March J., and Olsen, J., (1984) The New Institutionalism: Organizational Factors in Political Life. American Political Science Review 78 (3) 734-749

Ministry of Justice (2010) Breaking the Cycle: Effective Punishment, Rehabilitation and Sentencing of Offenders

http://webarchive.nationalarchives.gov.uk/20120119200607/http:/www.justice.gov.uk/consultation s/docs/breaking-the-cycle.pdf

Ministry of Justice (2013a) Competition Strategy for Offender Services

https://www.gov.uk/government/uploads/system/uploads/attachment data/file/217248/competiti on-strategy-offender-services.pdf

Ministry of Justice (2013b) Transforming Rehabilitation: A Strategy for Reform, London: The Stationery Office.

Ministry of Justice (2016) Prison Safety and Reform

https://www.gov.uk/government/uploads/system/uploads/attachment data/file/565014/cm-9350prison-safety-and-reform- web.pdf

Needham, C. (2008) 'Realising the potential of co-production: Negotiating improvements in public services', Social Policy and Society, 7(2), pp. 221-31.

Needham, C. and Carr, S. (2009) Co-production: an emerging evidence base for adult social care transformation, Research briefing 31, London, Social Care Institute for Excellence

Osborne, M.J., (2009) An Introduction to Game Theory: International Edition. Oxford: Clarendon Press 
Pestoff V (2012) Innovations in Public Services: Co-Production and New Public Governance in Europe in Botero A, Paterson A and Saad-Sulonen (Eds) Towards peer production in public services: Cases from Finland. Aalto University publication series Crossover 15/2012. Helsinki, Finland accessed online at: $\underline{\text { http://p2pfoundation.net/Co-Production and New Public Governance in Europe }}$

Rhodes, R., (1997) Understanding Governance, Buckingham Open University Press

Sangkhanate, A., (2012) Managing Prisons Using a 'Business-Like' Approach: A Case Study of the Scottish Prison Service https://www.era.lib.ed.ac.uk/handle/1842/6402

Sim, J (2008) An Inconvenient Criminological Truth: Pain, Punishment and Prison Officers in Bennet, J., Crewe., B and Wahidin A., (eds) Understanding Prison Staff, Cullompton, Devon pp187-209.

Solomon, E. and Edgar, K. (2004) Having Their Say: The work of prisoner Councils, London: Prison Reform Trust.

Sykes, G.M., (1958) Society of Captives: A Study of a Maximum Security Prison, Princeton: Princeton University Press.

User Voice (2010) The Power Inside: The Role of Prison Councils. User Voice

Weaver, B (2011) Co-Producing Community Justice: The Transformative Potential of Personalisation for Penal Sanctions. British Journal of Social Work: 41 (6):1038-1057. 